\title{
Effects of a Computer-Programmed Instructional Strategy on Basic Science Students' Learning Outcome in Two Instructional Settings in Ondo State, Nigeria
}

\author{
Ademiotan Moriyike LALEYE (Ph.D.) \\ Science Education Department, \\ Faculty of Education, \\ Adekunle Ajasin University, \\ Akungba- Akoko.
}

\begin{abstract}
.
This study investigated the effects of computer-based learning on students' academic performance and the learning setting that yields better when students are exposed to Computer- programmed Instructional Package .This research study tends to find out the efficacy of a Computer Assisted Instructional Package (CAIP) on students' performance in Basic Science. In actualising these, Quasi-experimental pre-test- posttest research design was used. Two secondary schools were purposively selected and assigned to Experimental groups 1 and 2 in equal numbers. Students in Experimental group 1 were exposed to CAIP individually and Experimental group II in Cooperative groups. An equivalent school was selected as control. 40 students in JSS 3 were randomly selected from each of the schools. Test-retest method was used in finding the reliability of BSAT which was used for collecting data. Result was 0.78 at 0.5 level of significance. Data collected was analysed using descriptive and inferential statistics of percentages and Analysis of Covariance (ANCOVA). The result of the analysis of co-variance and the Scheffé post hoc revealed that students taught with the developed package performed significantly better than their counterparts taught with conventional method of instruction.It was also discovered that the cooperative group, where a class of forty students are grouped into 10 enhanced better and faster learning than individualised learning. Results from the instructional settings show that knowledge acquisition was enhanced in all with the cooperative instructional setting performing better than their counterparts in individualised instructional setting and conventional group(individualized $=X=66.53$, cooperative $=X=76.75$, conventional $=X=59.40$ ). Consequently, the paper recommends that cooperative instructional setting should be encouraged in learning Basic Science.
\end{abstract}

Keywords: Knowledge acquisition, individualised setting, cooperative setting, basic science, Computer Assisted Instructional Package, Computer- Programmed Instructional Strategy.

\section{Introduction}

Technology has reduced the whole world to what is called a global village. The advancement of technology affects every aspect of human endeavour. Every country desires and aspires to be among those that have been rated as advanced. Information and Communication Technology (ICT) is therefore indispensable for any country that wants to belong to the global village. Muir (2000) believed strongly in the push for change in educational learning through technology. Integration of ICT into teaching-learning process is adopted through the use of computers and other technological materials in delivering curriculum contents. Research indicates that ICT can change the teaching and it is especially useful in supporting student centred approaches to instruction, developing the higher order skills and promoting collaborative activities (Haddad, 2003). Teaching and learning strategies can be strengthened by the use of computers (Laleye, 2016). According to Chado and Okwori (2014) computers ease instructional problems and can be exploited to enhance teaching and learning in all schools. 
Effective teaching and learning of science requires that science teachers use different methods and pedagogical skills to meet the demands of the science students, the challenge to science technologies and the demands of an ever changing educational environment. The teacher needs to discover new ways of motivating and stimulating the diverse abilities of the science students, many of whom have different learning styles and different orientations to life. Learning is a function of experience and a combination of cognitive, affective, psychomotor and physiological responses that characterized how each student learns (Ogunleye 2005). Also, Barron, Hebets, Cleland, Fitz, Hauber, \& Stevens(2015) define learning as the process by which a relatively lasting change in potential behaviour occurs that brought about by experience.

Part of the drive towards greater use of modern technology in education is aimed at modernizing schools and equipping the pupils of today with skills that will enable them to use such technology in the workplace once they leave school. According to Abba (2003), to benefit from the opportunities accrued to the use of technology in learning, effective strategies should be provided for acquiring and using knowledge. He explained further that science education in general and Basic Science in particular today, demand for teachers capable of handling the new technology and helping students interpret, re-package information and provide information - rich environment for communication.

Integration of ICT into the teaching-learning process is adopted through the use of computers and other technological gadgets for curriculum content delivery. The computer could be accessed individually or as a group unlike what we have in a conventional classroom where students are lumped together irrespective of their individual differences and class size. This study intends to find out the effect of a developed and validated package-Computer Assisted Instructional package (CAIP) on students' performance in Basic Science. Due to individual differences, some students learn well as individuals while some amidst their peers in form of group work. The research went further to find out the instructional setting that will yield better performance with CAIP.

Computer Programmed Instructional Strategy (CPIP) is a new teaching- learning strategy in which the topics to be taught are carefully planned, written and programmed in a computer which could be run at the same time in several computer units and allows each student a computer terminal (Kumar and Chaturvedi, 2014). Computer-Assisted Instruction (CAI) was defined by Sanni and Osungbemiro (2003) as programmed instructional material presented by means of computer or computer systems. They stressed further that what makes CAI most interesting is the degree of information between the users and the machine as facilitated by colourful and attractive machine interphase. They are of the opinion that the problem of lack of interest shown in serious scientific studies could be minimized by the adoption of a more innovative approach based on information technology. They argued further that it is only this that is capable of evoking the exclusion of all other established teaching methods. The innovative approach mentioned by these researchers is the use of Computer-Assisted Instructional Packages or Computer-Aided Learning or Electronic- Learning. Traynor (2003) is of the opinion that CAI programs increase student learning by increasing motivation. To facilitate the use of computer and packages in teaching and learning, acquisition of basic ICT skills and capabilities have recently been made mandatory as part of the national minimum standard for teacher education and first degree in education levels. Also, all universities in Nigeria have made ICT skills a requirement for all students in form of general studies that must be passed before graduation. The teacher education colleges have also been impacted by the current ICT revolution.

Before 1999,Basic science was taught as Integrated Science but in 1999 , Universal Basic Education (UBE) Programme was initiated which changed integrated science to Basic science in the first 9 years of the education system i.e. primary school and the junior secondary school. According to the designed curriculum for Basic Science, the curricular are designed to allow curriculum planners and implementers to adequately target pupils' needs and interests in a rapidly changing society like Nigeria. To fully realise the potential contributions of education to the achievement of the goals, the Federal Government took various measures to ensure proper implementation of the education policy at the upper basic level of education. These measures included learner centered educational activities for maximum self-development and fulfilment, activity-based practical teachings, supported experimental teachings, Information Technology and relatedness of education to overall community needs. In basic education, National values was made a core subject. It comprises Social Studies, Civic Education, Security Education, Islamic Studies (FRN, 2014). 
Since science is an indispensable phenomenon, it is imperative to look for better ways of teaching it. According to Agusiobo (2000), Basic Science curriculum planners stressed three basic strategies in teaching the subject. They are:

1. Use of discovery teaching tactics;

2. The inclusion of problem solving activities; and

3. The involvement of students in open ended laboratory exercise.

The problem facing the teaching and learning of Basic Science emanated from the curriculum planners. The syllabus drawn for the three years is too voluminous that teachers can hardly cover them within the duration of three periods per week 40 minutes per period. As a result of this, teachers rush to finish the syllabus but not to achieve the set goals and objectives (Afolabi, 2006). Difficult concepts, especially those that are abstract in nature could not be taught with ease using conventional method as it will consume more time and teachers will need time to gather materials for demonstration at different intervals.

Odetoyinbo (2004) recommended that Basic Science teachers should be exposed to various teaching techniques, such as inquiry, problem solving, co-operative learning and concept mapping among others to carry out hand-on tasks and activities in order to maximize the gains of Science. Instructional settings where learning takes place can assist the rate at which students' learn. Some students learn quickly when they sit alone to listen to the teacher while some learn faster amidst their peers in form of group work. This developed package (CAIP) was tested in two different instructional settings. That is, individualized and cooperative instructional settings. Various scholars have worked on the use of computer for learning and achievement in individualized classroom setting and co-operative learning environments.

Oloruntegbe and Odutuyi (2003) in their research work on innovative ICT-based approach to the teaching and learning of chemistry recommended that there must be micro-computers, at least one system to four students in cooperative instructional setting and minimum of 10 sets of computer for a class of 40 students for the ICT-based mode of instruction to be successful and effective. They went further to say that the classroom must be well ventilated and the sitting facilities must be very conducive. They also observed that a regular supply of electric power to operate and maintain the system is very essential. With the epileptic supply of electricity in Nigeria, there is always a need to have a stand-by generator that could be switched on when there is power outage.

Dauda, Mwanse and Dung (2003) in their research discovered that the computer-Assisted group was not better than the control group (Conventional group) and their F-test revealed no significant difference in the achievement of students in individual, co-operative and control groups of students. From their mean tables, it was realized that the co-operative group students recorded the highest mean scores of all. It was indicated that the co-operative use of the computer in learning generated more positive feelings, excitement and discussion than individualized computer instruction. Sherman (1989) and Okebukola (1995) in their studies supported this assertion. They made mention of the facilitative nature of co-operative learning on students' attitude. This research work intended to verify the learning environment that will generate more positive feelings. Basic science is meant to encourage students rekindle their interest and to enhance their enrolment for science related courses at the senior secondary school level. The margin of enrolment between science and non-science students is very wide (Oyediran, Agoro and Fabiyi, 2004). The margin is in favour of the latter, either at the senior secondary level or at the tertiary level of education. This is a problem because the teaching and learning of Basic science, which is the foundation for sciences as observed by the researcher is at the lowest ebb. When the foundation is good, the build-up will be strong.

\section{Problem of the study}

From statistical records of performance of students in science at the junior secondary school final examination, the performance of students could be rated as average and not improving (Exams and Records, 2010). Monk and Osborne (2000) opined that the deplorable level of achievement by students in later years of the $20^{\text {th }}$ century had necessitated the call by government and several researchers for more positive action to be initiated to put science achievement back on track. Also, in this age, technology has been integrated into every facet of the economy, education is not left out. Integration of ICT into the teaching -learning process is adopted through the use of technological gadgets for curriculum content delivery .The computer could be accessed individually or in groups unlike what we have in conventional classroom where students are lumped together irrespective of their individual differences and class size. 


\section{Purpose of the study}

This work found out the effects of a developed package (Computer-Assisted Instructional Package) on the learning outcome of students in Basic Science and the influence of instructional setting on their performance in Ondo State secondary schools in Nigeria.

\section{Methodology \\ Research design}

The study adopted the quasi-experimental pre-test-post-test design in checking the effect of CAIP on student's academic performance in the two instructional settings. The independent variable was study conditions. The study condition had three levels of treatments: the Computer-Assisted Instruction in individualized classroom setting (Experimental group 1), Computer-Assisted Instruction in co-operative classroom setting (Experimental group 2) and the Conventional classroom setting (Control group).

The research design is depicted as follows:

Table 1: Pretest Posttest Research Design Layout

\begin{tabular}{|l|l|l|l|}
\hline Groups & Pre-test & Treatment & Post-test \\
\hline Experimental Group 1 & $0_{1}$ & $\mathrm{X}_{1}$ & $0_{2}$ \\
\hline Experimental Group 2 & $0_{3}$ & $\mathrm{X}_{2}$ & $0_{4}$ \\
\hline Control Group & $0_{5}$ & $\mathrm{X}_{\mathrm{o}}$ & $0_{6}$ \\
\hline
\end{tabular}

\section{- Key to the table}

$\mathrm{X}_{1}=$ Treatment of the Individualized CAI Group.

$\mathrm{X}_{2}=$ Treatment of the Cooperative CAI Group.

$0_{1}=$ Pre-test scores of the individualized CAI Instructional group.

$\mathrm{O}_{2}=$ Post-test scores of the individualized CAI Group.

$0_{3}=$ Pre-test scores of the cooperative CAI Group.

$0_{4}=$ Post-test scores of the cooperative CAI Group.

$0_{5}=$ Pre-test scores of the control Group.

$0_{6}=$ Post-test scores of the control Group.

$\mathrm{X}_{\mathrm{o}}=$ No treatment

\section{Research Hypothesis}

Hypothesis raised to guide the study was:

There was no significant difference in the performance of students exposed to Computer-Assisted Instructional Package (CAIP) in individualized instructional setting and cooperative instructional setting; and those taught with conventional method of instruction.

\section{Population, Sample and Sampling Technique}

All the junior secondary school students from JSS1-3 make up the total population of the study. Therefore, the target population for evaluation of the developed package was all JSS 3 students in Ondo State. Purposive sampling technique was used in selecting the samples. The criteria set for this study required that research samples are selected from schools where students and their teachers are computer literate and there are enough set of computers that will serve the study groups. This implies that the sampled school for individualized instructional setting must have a minimum of 40 sets of computer while 10 sets of computer must be available in the selected school for co-operative instructional setting. Purposive sampling method was used to select the junior secondary schools that satisfied the set criteria. Stratified random sampling was used to select 3 junior secondary schools from the schools that met up with the set criteria.

The schools were selected because they have:

Well-equipped computer laboratories with more than required number of set of computers and good stand-by generators that were needed for the study; 
The students and their teachers are computer literate to work on the developed package CAIP with little or no assistance. The schools are connected to the internet to download browsers for the developed CAIP if need be. In each of the schools, 60 students were selected from the JSS 3 class out of which 40 were purposively selected. In order words, result of 120 students was used for final analysis of data.

\section{Research Instruments}

The instruments for this research were (1) Treatment instrument which is the Computer-Assisted Instructional Package (CAIP) and (2) Test instrument which is Basic Science Achievement Test (BSAT).

\section{Test Instrument}

Basic Science Achievement Test (BSAT) was developed by the researcher and is based on the content of CAIP. It is a diagnostic test that is made up of 25 item multiple-choice objective tests with four options. BSAT was given to all the participants at the pretest and posttest levels.

The pretest and posttest were graded and scored. Four (4) marks are awarded to each item, giving a total mark of one hundred (100) i.e. $4 \times 25=100$. The score therefore formed the basic data for testing hypothesis. The result obtained from the test was used to determine the Effect of Computer-Assisted Instructional Package on Junior Secondary Students' Performance in Basic Science.

\section{Reliability of the test instrument}

Test-retest method was used to find the reliability of the test instrument. An equivalent fourth school was selected to establish the reliability of the test instrument. BSAT was administered to the group of 30 students in JSS3 in the school. After a period of two weeks, the same test BSAT was re-administered to the same group of students that sat for the previous test. The individual's score from the two tests were correlated and analyzed using Pearson Product Moment Correlation (PPMC). The result was 0.78 at 0.05 levels of significance.

\section{Treatment and Administration of instrument}

For the Experimental group 1, 40 desktop computers with $18 \mathrm{~cm}$ monitors were used while experimental group 2 used 10 desktop computers. Experimental group 2 came to the studio in groups, each group consisting of four students stayed with each of the computers. In the control group school, their teacher taught the topics on the CAIP using the necessary instructional materials. Lessons were conducted after school hours in order not to disturb their normal school work. BSAT for the pre-test was rearranged and administered to the students as posttest after treatment.

\section{Procedure for data analysis}

The scores of students in BSAT were statistically analysed using Analysis of Co-variance (ANCOVA) to test the hypotheses raised for the research. Since there was significant difference, the post-hoc analysis was done using scheffe-post hoc test and Multiple Classification Analysis (MCA). Hypothesis was tested at 0.05 level of significance.

\section{Results}

Table 1: Academic performance of subjects exposed to Individualized, Cooperative and Conventional Instructional strategies using ANCOVA.

\begin{tabular}{|l|l|l|l|l|l|}
\hline Source & SS & Df & MS & $\mathbf{F}_{\text {cal }}$ & $\mathbf{F}_{\text {table }}$ \\
\hline $\begin{array}{l}\text { Corrected } \\
\text { Model }\end{array}$ & 36298.67 & 3 & 12099.56 & 106.82 & 2.68 \\
\hline $\begin{array}{l}\text { Covariate } \\
\text { Pretest) }\end{array}$ & 30214.15 & 1 & 30214.15 & 2 & 3.92 \\
\hline Group & 3120.29 & 2 & 1560.15 & 13.77 & 3.07 \\
\hline Error & 13138.92 & 116 & 113.27 & & \\
\hline $\begin{array}{l}\text { Corrected } \\
\text { Total }\end{array}$ & 49437.59 & 119 & & & \\
\hline Total & 597133.00 & 120 & & & \\
\hline
\end{tabular}

$\mathrm{P}<0.05$ 
Table 1 presents the academic performance of students exposed to different treatments in Basic Science. The result shows that F-calculated (13.77) is greater than F-tabulated (3.07) at 0.05 level of significance. The null hypothesis was rejected. Therefore, there is significant difference in the performance of students exposed to computer-Assisted Instructional Package in individualized instructional setting and cooperative instructional setting; and those taught with conventional method of instruction. To determine the pair of treatment groups that are significantly different in means at 0.05 levels, Scheffé Post Hoc Test was used. The result is shown in Table 2

Table 2: Scheffé Analysis of Students’ Academic Performance among the Treatment Groups

\begin{tabular}{|l|l|l|c|l|l|}
\hline Group & Individualized & Cooperative & Conventional & X & N \\
\hline Individualized & & & & 66.53 & 40 \\
\hline Co-operative & & & $*$ & 76.75 & 40 \\
\hline Conventional & & & & 59.40 & 40 \\
\hline
\end{tabular}

* Mean difference is significant at the 0.05 level.

The result shows that there is significant difference between the academic performance of students exposed to cooperative and conventional learning strategies at 0.05 level of significance. However, the mean difference between individualized and conventional, individualized and cooperative is not statistically significant at 0.05 levels in each case. In order to test the effect of treatment on the adjusted posttest mean scores of subjects, Multiple Classification Analysis (MCA) was used. The result is presented in Table 3.

Table 3: Multiple Classification Analysis of Treatment and students' Academic Performance in Basic Science

\begin{tabular}{|c|c|c|c|c|c|}
\hline \multicolumn{6}{|c|}{ Grand Mean $=67.56$} \\
\hline $\begin{array}{l}\text { Variable } \\
\text { Category }\end{array}$ & $\mathbf{N}$ & $\begin{array}{l}\text { U adjusted } \Delta \\
\text { evn }\end{array}$ & Eta & $\begin{array}{l}\text { Adjusted for } \\
\text { Independent + } \\
\text { Covariate }\end{array}$ & Beta \\
\hline Individualized & 40 & -1.03 & & -2.77 & \\
\hline Cooperative & 40 & 9.19 & 1.34 & 7.11 & .82 \\
\hline Conventional & 40 & -8.16 & & -4.34 & \\
\hline \multicolumn{6}{|l|}{ MultipleR $^{2}$} \\
\hline MultipleR & & & & .82 & \\
\hline
\end{tabular}

Table 3 presents the Multiple Classification Analysis of treatment and adjusted posttest mean scores of students in Basic Science. The result shows that students exposed to cooperative learning environment had the highest adjusted posttest mean score of $74.67(67.56+7.11)$. This is loosely followed by those in the individualized learning environment with an adjusted posttest mean score of $66.53(67.56+(-1.03)$ while those in the conventional group recorded the least adjusted posttest mean score of $59.40(67.56+(-8.16)$. This implies that cooperative and individualized learning strategies constitute potent instructional strategies for enhancing better academic performance of students in Basic Science. There was significant difference in the performance of students exposed to Computer-Assisted Instructional Package in the individualized and cooperative learning setting as performed better than their counterparts in the conventional group with the best performance from the cooperative group (individualized $=X=66.53$, cooperative $=X=76.75$, conventional $=X=59.40$ )

Investigating the effect of CAIP on students' performance in Basic Science, the result of the analysis of covariance and the Scheffé post hoc using the developed CAIP revealed that students taught with the developed package performed significantly better than their counterparts taught with conventional method of instruction. Result of the analysis of co-variance and the Scheffé post hoc on the effect of CAIP on students' performance in Basic Science revealed that students taught with the developed package performed significantly better than their counterparts taught with conventional method of instruction. This findings is in line with the findings of Sasser (1990-1991) on mathematics, Odunbunmi and Balogun (1991), Kulik and Kulik (1991), Adeniyi (1997) on physics, Fletcher-flin and Gravatt (1995), Christmann, Badgett and Lucking (1997), Eegunjobi (2002) on geography, Jenks and Springer (2002), Philip and Moss (2003) on biology, Bassey, (2006), Afolabi, (2006), Oyelekan and Olorundare (2009) on chemistry, Chado and Okwori (2014) on metalwork technology and 
Mahmud, R., Ismail, M., Kiaw, L. (2009). They all worked on efficacy of CAI at the secondary and postsecondary levels and discovered that students performed better when taught with Computer Assisted Instructional Packages than their counterparts taught the same topics using conventional method of teaching. Students in the experimental groups were exposed to the developed package in two instructional settings; these are the individualized and cooperative. Two different schools were used for each of the settings and four students made a group in cooperative settings (quad group). On performance in Basic Science Achievement Test, student in the cooperative group performed significantly better than their colleagues in the individualized learning settings. This is in line with the findings of Dauda, Nwanse and Dung (2003), Daramola (2007), and Imhanlahimi and Imhanlahimi (2008) that students taught through cooperative or interactive Computer Assisted learning strategy achieved significantly higher than those taught in individualized learning setting. This may be as a result of the interaction with one another by the students in the cooperative group Also, shy students and introverts can feel free in their own student-centred environment.

\section{Conclusion}

This research work has shown that there has been deterioration in the performance of students in Basic Science. Many factors are responsible for this. The fault may be from the teacher or the learner. The curriculum planned could not be spared. In order to find corrective measures to the dwindling performance in Basic Science, the findings of the study revealed that the students exposed to the use of CAIP in the two instructional settings (individual and cooperative) significantly performed better than their colleagues taught using conventional method of teaching. This implies that CAIP could be effectively utilized to teach the students Basic Science since learning is enhanced.

\section{References}

[1] Abba, I. (2003). The role of ICT in the effective teaching of integrated science: A suggested model. Proceedings of the $44^{\text {th }}$ annual conference of STAN. Heinemann education books (Nig) Plc.Pg 163 166

[2] Adeniyi, A. (1997). Computer aided instruction and achievement in physics. STAN $40^{\text {th }}$ Anniversary Conference Proceeding. Pg. 257-260.

[3] Afolabi, A. O. (2006). Effects of computer- assisted instructional package in biology in Oyo, Nigeria. Unpublished Ph.D thesis, University of Ilorin.

[4] Agusiobo, B.C. (2000). The level of use (LOU) of resources in the integrated science master plan by the teacher. $41^{\text {st }}$ STAN Annual Conference Proceeding.

[5] Barron, A. B., Hebets, E. A., Cleland, T. A., Fitz patrick, C. L., Hauber, M. E., \& Stevens, J. R. (2015) (in press). Embracing multiple definitions of learning. Trends in Neurosciences DOI:10.1016/j.tins.2015.04.008)

[6] -Bassey, E.U. (2006). Effect of information and communication technology on students academic performance in SSS biology. Ife Journal of Theory and Research in Education. (IJOTRE). Vol. 9.(2). $108-115$

[7] Chado, M. D. \& Okwiri, O. R. (2014). The effect of computer-assisted instructional pacakage for teaching metalwork technology (MWT) at Nigeria certificate in Deucalion (technical) level. International Journal of Academic Research in Progressive Education and Development- Vol. 4(1)

[8] Christmann, E., Badget, J., \& Lucking, R. (1997). Progressive comparism of the effects of computer assisted instruction on the academic achievement of secondary school students. Journal of Research on Computing in Education, 29(4), 325-357.

[9] Dauda, D.M; Mwanse, E.D, and Dung, C.J. (2003). Students' attitude to the use of the computer for learning and achievement in scientific concepts. $44^{\text {th }}$ Annual Conference Proceedings of STAN. Pgs 29-32.

[10] Eegunjobi, A.O. (2002). The efficacy of two CAI modes of learner's practical geography achievement of the secondary school level in Ibadan metropolis; Nigeria. Paper Delivered at the NAEMY Conference. 20-23, Nov., 2003.

[11] Federal Republic of Nigeria (2014). National Policy on Education (6 ${ }^{\text {th }}$ Edition). Abuja: NERDC press.

[12] Fletcher F.C.M., and Gravatt B. (1995). "The efficacy of computer assisted instruction (CAI): a meta analysis." Journal of Educational Computer Research, 12(3), 219-242. 
[13] Haddad, W, D. (2013). Is Instructional technology a must for learning? Retrieved from http:www.techknowlogia.pdf.

[14] Imhanlahimi, E.O. and Imhanlahimi, R.E. (2008). An evaluation of the effectiveness of Computer Assisted learning strategy and Expository method of Teaching Biology: A case study of Lumen Christi International High School, Benin City, Nigeria. Journal of Social Sciences, 16(3): 215 - 220.

[15] Jenks, M.S. and Springer, J.M. (2002). A view of research on the efficacy of CAI. Electronic Journal for the Integration of Technology in Education, 1(2), 43-48.

[16] Kulik, J.A., (1983). Effect of Computer-Based Teaching in Learner. Paper presented at the national forum of the college board symposium on computer competency and the curriculum, Dallas, Texas. (ERIC Document Reproduction Service No. ED 245-877).

[17] Kumar, R. \& Chaturvedi, S. (2014). Effectiveness of computer assisted instructional package as remedial teaching for learning disabled children. Learning Community: 5(2\&3). DOI: 10.5958/2231-458X.2014.00016.5

[18] Laleye, A. M. (2016). Development and validation of a computer- assisted instructional package for learning basic science in Nigeria. Journal of Science, Technology, Mathematics and Education (JOSTMED), Vol 12(1), Federal University of Technology, Minna.

[19] Mahmud, R., Ismail, M., Kiaw, L. (2009). Development and evaluation of a CAI courseware 'GReflect' on students' achievement and motivation in learning mathematics. European Journal of Social Sciences - Vol. 8, Number 4.

[20] Monk, M. and Osborne, J. (2000). 'Good Practices in Science Teaching' Birmingham: Open University Press.

[21] Muir, M. (2000). What underachieving middle school students believe motivates them tolearn. (Unpublished doctoral dissertation). University of Maine. [On-line]. Retrieved from http://www.mcmel.org/DisWeb/index.html

[22] Odetoyinbo, B.B. (2004). "Evaluation of the Nigeria Integrated Science Programme in Junior Secondary Schools". An Unpublished Ph.D Thesis. university of Ibadan, Ibadan.

[23] Odubunmi, O. and Balogun, T.A. (1991). The effect of laboratory and lecture teaching methods on the achievement in integrated science. Journal of Research in Science Teaching. 28. 213-224.

[24] Ogunleye, A. (2005). Enhancing science learning by understanding teaching and learning styles: workshop on teaching with styles. $46^{\text {th }}$ Annual Proceeding of STAN

[25] Okebukola, P. (1995). Breaking the barrier to good quality education in Nigeria. Federal College of Education Convocation Series No2.

[26] Oloruntegbe, K.O. and Odutuyi, M.O. (2003). An innovative ICT-based approach to the teaching and learning of chemistry. Proceedings of the $44^{\text {th }}$ Annual Conference of the Science Teachers Association of Nigeria (STAN). 135-138.

[27] Oyediran, A.M, Agoro, A.A and Fabiyi, O.O. (2004). A multimedia approach to the teaching of some difficult topics in integrated science. Journal of STAN 39(1,2). 10-15.

[28] Oyelekan, O.S. and Olorundare, A.S. (2009). Development and validation of a computer instructional package on electrochemistry for secondary schools in Nigeria. International Journal of Education and Development Using ICT - Vol. 5, No. 2 (2009). www.openjournalsystem.org

[29] Philip, T., and Moss, G.D. (1993). Can CAI'S biology packages used to replace teachers? Journal of Biology Education, 27(3), 213-215.

[30] Sanni, R.O. and Osungbemiro N.R. (2004). An Innovative, I.T based approach to the teaching of biological sciences at the SS level of education, STAN: Ondo State Journal of STAN. 94-100.

[31] Sasser, J.E. (1990-91). "The effects of using computer tutorials as homework assignments on mathematics achievement of elementary education Majors"Journal of Computers in Mathematics and Science Teaching.10 (2), 95-102.

[32] Sherman, L.W. (1989). Quoted in Jegede S.A. (2003). The effect of the component task analysis model of instruction on students' performance in chemistry. Unpublished Ph.D Thesis UNAD.

[33] Traynor, P. L. (2003). Effects of computer-assisted-instruction on different learners. Journal of Instructional Psychology, 30(2). Retrieved from http://www.questia.com 